\title{
НАЛОГООБЛОЖЕНИЕ ФИЗИЧЕСКИХ ЛИЦ
}

\author{
Светлов И. А., Забайкамов А. П.
}

\section{НЕКОТОРЫЕ АСПЕКТЫ СОАЕРЖАНИЯ ПОНЯТИЯ «ПРЕАПРИНИМАТЕАЬСКАЯ АЕЯТЕАЬНОСТЬ В ПРАКТИКЕ ПО НААОГОВЫМ СПОРАМ}

\begin{abstract}
Аннотация. Авторами на материалах судебной практики рассмотрен вопрос о том, является ми предпринимательскойдеятельностью ситуачия, когда собственник - физическое лицо сдает принадяежащее ему имущество в аренду. Предметом рассмотрения являются противоречия, возникающие между налоговыми органами и налогоплательщиками в данной сфере. Отмечается, что поскольку налоговое законодательство не содержит собственной дефиниции понятия «предпринимательскал деятельность», то правоприменители вынуждены применять положения гражданского права. При этом неопределенность формулировок приводит к необходимости рассмотрения обстолтельств конкретного дела. Методология исследования базируется на традиционных дяя юридической науки принципах, приемах и методах: диалектика, анализ, синтез, аналогия, дедукции и т. д. Авторы обосновывают вывод о том, что ситуачия, при которой физччекие мица сдают в аренду имущество, приобретенное дяя мичного, семейного и иного подобного использования, не может считаться предпринимательской деятельностью. Соответственно, полученные в таком случае в виде арендной платы доходы не являются доходами, получаемыми в связи с осуществлением предпринимательской деятельности.
\end{abstract}

Ключевые слова: предпринимательскал деятельность, налог, налоговый спор, аренда, физическое мицо, предприниматель, судебная практика, гражданин, арендная плата, доход.

Review. Based on judicial practices, the authors of the present article are trying to answer the question whether entrepreneurial activity can be considered as the situation when a property owner (physical entity) leases the property he or she owns. The subject of the present research is the contradictions arising between tax authorities and taxpayers regarding the matter. The authors note that providing that the tax legislation does not offer its 


\section{ФИНАНСОВОЕ ПРАВО И УПРАВ АЕНИЕ • 4 • 2015}

own definition of 'entrepreneurial activity', law enforcement officials have to apply provisions of civil law. In this case, uncertain legal statements cause the need to view circumstances of a particular case. The methodology of the research is based on traditional legal principles, techniques and methods such as dialectics, analysis, synthesis, analogy and deduction and etc. The authors conclude that the situation when a physical entity leases out his property obtained for personal, family and other purposes can't be considered as entrepreneurial activity. Accordingly, the rent isn't considered as a revenue obtained in a result of entrepreneurial activity.

Keywords: judicial practice, entrepreneurial (business) activities, tax, rent, tax dispute, individual, entrepreneur (businessman), citizen, rental fee, income.

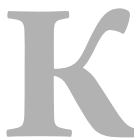

ажАый обязан пиатить законно установменные налоги и сборы», - закрепляет одну из немногочисленных конституционных обязанностей Основной закон России [1]. ОАнако Аля того, чтобы точнее определить, что относится к категории «законно установленные намоги и сборы» необходим тщательный анализ судебной и арбитражной практики [2].

Налоговая система Российской Федерации, достаточно многообразна и включает самые различные объекты налогообложения и налоговые базы. ПреАставляется, что она позволяет взыскивать Аостаточно среАств, чтобы наполнить бюАжеты всех уровней. Но, к сожалению, современная экономическая ситуация объективно уменьшает возможности налогоплательщиков. Это подталкивает налоговые органы к поиску новых, порой довольно креативных, приемов. Конечно, налоговых инспекторов нельзя сравнить с прибыльщиками времен Петра Великого, работа которых заключалась том, чтобы «сидеть и чинить государю прибыли», т. е. изобретать новые источники государственного дохода [3]. Они ограничены указаниями Намогового кодекса Российской Федерации [4] (Аалее - НК РФ) и иных нормативных актов. В тоже время, новые толкования существующих норм появляются с завидной регулярностью. Причем фискальные органы не всегда придерживается буквы закона, и порой выходят за его пределы Аля получения Аополнительных, но не обоснованных поступлений в бюАжет. ИАеи, как правимо, апробируются «на местах». Прошедшие проверку в судебной системе распространяются на федеральный уровень, а отвергнутые - забываются.

Отдельно следует отметить, что рассмотрение указанной категории Аел преАставмяет интерес не только Аля ученых и практикующих специалистов по налоговому праву, но и иных отраслей права.

Так, в открытом судебном засеАании в г. Ельце было рассмотрено гражданское дело Инспекции Федеральной налоговой скужбы (Аалее - ИФНС, Инспекция) к гражданину А. о взыскании налогов, пени и штрафов [5].

В обоснование иска ИФНС привела материалы выездной налоговой проверки, по результатам которой бымо вынесено решение о привлечении гражданина А. к налоговой ответственности. Инспекция полагала, что налогоплательщик, укмонившись от регистрации в качестве индивидуального преАпринимателя, в период с 2008 по 2010 гоА фактически занимался преАпринимательской Аеятельностью: Приобрел и саавал в аренАУ Подконтрольным организациям транспортные среАства без экипажа. Соответственно, он неправомерно не исчислял и не уплачивал налог на Аоходы физических Аиц, еАиный социальный налог и налог на Аобавленную стоимость.

Факты совершения сделок аренды, размер и порядок пиатежей, расчеты налогов, пеней и штрафов сторонами не оспаривался. Ключевым моментом этого налогового спора стал вопрос о том, явмялась ми деятельность гражАанина А. преАпринимательской.

В обоснование своей позиции ИФНС опиралась на Письмо Министерства финансов Российской Федерации от 22 сентября 2006 г. № 0305-01-03/125 «О налогообложении НАФА Аоходов физического Аица от саачи в аренду (внаем) жилых помещений» [6]. В нем, Аополняя Аефиницию ст. 2 ГражАанского кодекса Российской Федерации [7] (Аалее - ГК РФ), Министерство финансов высказывало мнение о том, что 
о наличии в Аействиях гражАанина признаков преАпринимательской Аеятельности могут свиАетельствовать, в частности, следующие факты:

- изготовление ики приобретение имущества с целью последующего извлечения прибыли от его использования или реализации;

- учет хозяйственных операций, связанных с осуществлением сАелок;

- взаимосвязанность всех совершенных гражАанином в опреАеленный период времени сАелок;

- устойчивые связи с продавцами, покупатемями, прочими контрагентами.

Соответственно, подтвержАая статус Аеятельности гражданина А. как преАпринимательской, ИФНС подчеркивала слеАующие факты:

- налогоплательщик приобрел транспортные средства (Фольксваген-Транспортер и ФорА-Транзит) специамьно Амя передачи их в аренду;

- налогопиательщик получал АохоА систематически в течение нескольких налоговых периодов;

- налогоплательщик является учредите-

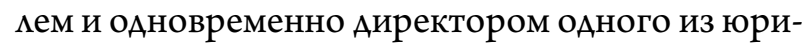
Аических мица - арендаторов, а так же является учреАителем Аругого юридического мица, которому он саавац транспортные средства в аренду.

Ответчик исковые требования не признак, ПривоАЯ слеАующие АовоАЫ:

- в качестве инАивидуального преАпринимателя он не зарегистрирован, преАпринимательскую Аеятельность в проверяемый период не осуществлям;

- транспортные средства он приобретал

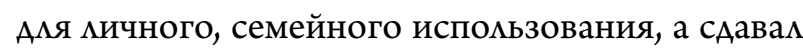
временно, когАа не было необходимости в таком использовании;

- законодатемьство допускает слачу имущества в аренду физическими мицами и никак не связывает это со статусом преАпринимателя;

- он получал обусловленный Аоговором АОхоА в виАе аренАной платы, явмяющийся объектом обложения НАФА (пп. 4 п. 1 ст. 208 НК РФ), но при этом не осуществмяет какой-либо экономической деятемьности на свой страх и риск;

- экономическую Аеятемьность осуществмяли организации-арендаторы; они же нес- ми все расходы по содержанию, экспиуатации, ремонту, страхованию транспортных среАств и иные связанные расходы;

- в ходе налоговой проверки установлено, и ИФНС не оспаривается, что с Аоходов от сАачи в аренду транспортных среАств производикась упиата НАФ

- в случае регистрации в качестве преАприниматемя, он мог бы применять упрощенную систему налогообложения или систему налогообложения в виде еАиного налога на вмененный

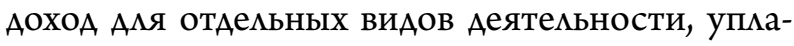
чивая меньшие суммы, чем удержания по налогу на Аоходы физических миц, которые фактически произвоАились;

- налоговый орган не представиц доказатемьств учета операций, связанных с совершаемыми сАелками.

СуА первой инстанции встац на сторону ответчика, и мотивировац это следующим образом.

Нормы-Аефиниции, опредемяющие преАпринимательскую Аеятельность, в НК РФ отсутствуют. Согласно абзацу 3 п.1 ст. 2 ГК РФ преАпринимательской является самостоятельная, осуществляемая на свой страх и риск Аеятельность, направленная на систематическое покучение прибыли от помьзования имуществом, продажи товаров, выполнения работ или оказания ускуг мицами, зарегистрированными в этом качестве в установленном законом порядке.

Согласно ст. 608 ГК РФ право сАачи имущества в собственность принаАлежит собственнику Аанного имущества, а согласно ст. 209 ГК РФ собственник вправе совершать в отношении

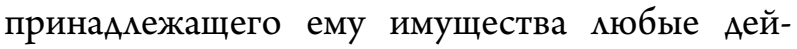
ствия, не противоречащие закону, в том числе саавать в аренду имущество.

В соответствии с Общероссийским классификатором виАов экономической Аеятельности [8], экономическая Аеятельность имеет место в случае, если ресурсы (оборудование, рабочая сила, технологии, сырье, материалы, энергия, информационные ресурсы) объеАиняются в произвоАственный комплекс, имеющий целью произвоАство проАукции (выполнение работ, оказание услуг). Закон связывает необходимость регистрации физического мица в качестве индивидуацьного преАприниматемя с осущест- 


\section{ФИНАНСОВОЕ ПРАВО И УПРАВ АЕНИЕ • 4 • 2015}

влением Аеятельности особого роАа, а простого совершения гражАанином возмезАных сАелок неАостаточно Аля признания его преАпринимателем, если они не образуют деятельности.

К тому же Аоходы от сАачи в аренАу имущества поименованы в ст. 208 НК РФ как самостоятельный виА АохоАов, являющийся объектом $\mathrm{H} А Ф \Lambda$.

Суд акцентировам внимание на том, что Аоговоры были заключены с ответчиком как с физическим мицом. Техническое обслуживание и капитальный и текущий ремонт произвоАились арендатором. Хозяйственный учет операций по сааче в аренду транспортных среАств ответчик не вел.

Так же из материалов Аела винно, что налоговыми агентами в полной мере производилось удержание и перечисление НАФА на Аоходы полученные гражАанином А., в том числе и на Аоходы, покученные от сАачи имущества в аренАу, и Аанные налоги принимались налоговым органом.

СуА обратим внимание и на тот факт, что гражАанин А. является учреАителем и оАновре-
Менно Аиректором ОАного из юриАических Аица-арендаторов, а так же явмяется учреАителем Аругого юридического мица - арендатора. По мнению суАа, это ясно говорит о том, что сАача имущества в аренду не явмяется Аця ответчика-налогопиательщика основным виАом деятельНОсТИ И ОсНОВНЫМ ВИАОМ АОХОАа.

Решение суда первой инстанции была оспорено в апемляционном поряАке, но осталось без изменений. Иные возможности Аля обжамования налоговые органы не использовали.

Указанное дает основание утверждать, что физические мица - собственники имущества имеют право саавать его в аренду именно как физические мица, а не как индивидуамьные преАприниматели. ПравАа, речь илет об имуществе,

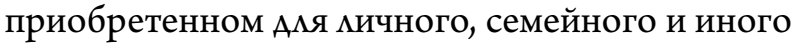
подобного использования.

Такая Аеятемьность не может считаться преАпринимательской, а полученные Аоходы в виде арендной платы - доходами, получаемыми в связи с осуществлением преАпринимательской Аеятельности. Но, конечно же, с Аанных Аоходов Аомжен платиться НАФА.

\section{БИБАИОГРАФИЯ}

1. Конституция Российской Федерации: принята всенародным голосованием 12 декабря 1993 г. (реА. от 21.07.2014) // Собрании законодательства Российской Федерации. 2014. № 31. Ст. 4398.

2. Боровикова Е.В. Спорные вопросы исчисления НАФА и арбитражная практика их разрешения // Налоги и налогообложение. 2012. № 7. С. 51-58.

3. КАючевский В. Курс русской истории. Соч. в 8 т. М., 1958. Т. 4.С. 130-133.

4. Налоговый кодекс Российской Федерации (часть первая) от 31 июмя 1998 г. № 146-Ф3 // Собрание законодательства Российской Федерации. 1998. № 31. Ст. 3824; Налоговый кодекс Российской Федерации (часть вторая) от 05 августа 2000 г. № 117-Ф3 // Собрание законодательства Российской Федерации. 2000. № 32. Ст. 3340.

5. Решение Елецкого городского суда Аипецкой области от 21 августа 2012 г. по гражАанскому деку № $2-1745 / 2012$.

6. Письмо Министерства финансов Российской Федерации от 22 сентября 2006 г. № 03-05-01$03 / 125 \ll$ О налогообложении НАФ $\Lambda$ Аоходов физического мица от сАачи в аренду (внаем) жилых помещений» // Учет. Налоги. Право. (Официальные Аокументы). 2006. 17 октября 2006 г.

7. ГражАанский кодекс Российской Федерации (часть первая) от 30 ноября 1994 г. № 51-Ф3 // Собрание законодательства Российской ФеАерации. 1994. № 32. Ст. 3301; ГражАанский кодекс Российской Федерации (часть вторая) от 26 января 1996 г. № 14-Ф3 / Собрание законодательства Российской Федерации. 1996. № 5. Ст. 410.

8. Общероссийский классификатор видов экономической деятельности (ОКВЭА) ОК 029-2001 (КАЕС РеА. 1), принятый и введенный в действие Постановлением ГосстанАарта России от 06.11.2001 № 454-ст // http://base.consultant.ru/cons/cgi/online. cgi?req=doc;base $=\mathrm{LAW} ; \mathrm{n}=178809$ 


\section{REFERENCES}

1. Konstitutsiya Rossiiskoi Federatsii: prinyata vsenarodnym golosovaniem 12 dekabrya 1993 g. (red. ot 21.07.2014) // Sobranii zakonodatel'stva Rossiiskoi Federatsii. 2014. № 31. St. 4398.

2. Borovikova E.V. Spornye voprosy ischisleniya NDFL i arbitrazhnaya praktika ikh razresheniya // Nalogi i nalogooblozhenie. 2012. № 7. C. 51-58.

3. Klyuchevskii V. Kurs russkoi istorii. Soch. v 8 t. M., 1958. T. 4. S. 130-133.

4. Nalogovyi kodeks Rossiiskoi Federatsii (chast’ pervaya) ot 31 iyulya 1998 g. № 146-FZ // Sobranie zakonodatel’stva Rossiiskoi Federatsii. 1998. № 31. St. 3824; Nalogovyi kodeks Rossiiskoi Federatsii (chast' vtoraya) ot 05 avgusta 2000 g. № 117-FZ // Sobranie zakonodatel'stva Rossiiskoi Federatsii. 2000. № 32. St. 3340.

5. Reshenie Eletskogo gorodskogo suda Lipetskoi oblasti ot 21 avgusta 2012 g. po grazhdanskomu delu № 2-1745/2012.

6. Pis'mo Ministerstva finansov Rossiiskoi Federatsii ot 22 sentyabrya 2006 g. № 03-05-01-03/125 $\ll \mathrm{O}$ nalogooblozhenii NDFL dokhodov fizicheskogo litsa ot sdachi $\mathrm{v}$ arendu (vnaem) zhilykh pomeshchenii > // Uchet. Nalogi. Pravo. (Ofitsial'nye dokumenty). 2006. 17 oktyabrya $2006 \mathrm{~g}$.

7. Grazhdanskii kodeks Rossiiskoi Federatsii (chast' pervaya) ot 30 noyabrya 1994 g. № 51-FZ // Sobranie zakonodatel'stva Rossiiskoi Federatsii. 1994. № 32. St. 3301; Grazhdanskii kodeks Rossiiskoi Federatsii (chast' vtoraya) ot 26 yanvarya 1996 g. № 14-FZ // Sobranie zakonodatel'stva Rossiiskoi Federatsii. 1996. № 5. St. 410.

8. Obshcherossiiskii klassifikator vidov ekonomicheskoi deyatel'nosti (OKVED) OK 029-2001 (KDES Red. 1), prinyatyi i vvedennyi v deistvie Postanovleniem Gosstandarta Rossii ot 06.11.2001 № 454-st // http://base.consultant.ru/cons/cgi/online.cgi?req=doc;base=LAW;n=178809 